\title{
Uji aktivitas antibakteri ekstrak etanol annona muricata linn. terhadap vibrio cholerae secara in vitro
}

\author{
Herwandi ${ }^{1}$, Mahyarudin $^{2}$, Effiana ${ }^{3}$ \\ 1. Program Studi Kedokteran, Fakultas Kedokteran, Universitas Tanjungpura; 2. Departemen \\ Mikrobiologi, Fakultas Kedokteran, Universitas Tanjungpura; 3. Departemen Imunologi, Fakultas \\ Kedokteran, Universitas Tanjungpura
}

Korespondensi: Mahyarudin, email: mahyarudin@medical.untan.ac.id

\begin{abstract}
Abstrak
Vibrio cholerae merupakan satu di antara bakteri penyebab terjadinya diare. Beberapa penelitian menunjukkan terjadinya multidrug resistant terhadap V. cholerae. Daun Sirsak (A. muricata L.) yang memiliki kandungan metabolit sekunder dapat berfungsi sebagai senyawa antibakteri. Tujuan: Untuk mengetahui aktivitas antibakteri etanol daun sirsak dalam menghambat pertumbuhan $V$. cholerae. Metode: Daun sirsak diekstraksi dengan metode maserasi menggunakan pelarut etanol. Skrining fitokimia menggunakan uji tabung. Uji aktivitas antibakteri menggunakan metode difusi cakram dengan konsentrasi $25 \mathrm{mg} / \mathrm{ml}, 50 \mathrm{mg} / \mathrm{ml}, 100 \mathrm{mg} / \mathrm{ml} .200 \mathrm{mg} / \mathrm{ml}, 400 \mathrm{mg} / \mathrm{ml} .500 \mathrm{mg} / \mathrm{ml}$. Kontrol positif yang digunakan adalah Siprofloksasin $5 \mu \mathrm{g} /$ disk sedangkan kontrol negatif yang digunakan adalah tween 80. Hasil: Metabolit sekunder yang terkandung dalam ekstrak etanol daun sirsak yaitu alkaloid, fenol, flavonoid, saponin dan tanin. Ekstrak etanol daun sirsak (A. muricata L.) memiliki aktivitas antibakteri terhadap $V$. cholerae pada konsentrasi $25 \mathrm{mg} / \mathrm{ml} ; 50 \mathrm{mg} / \mathrm{ml} ; 100 \mathrm{mg} / \mathrm{ml} ; 200$ $\mathrm{mg} / \mathrm{ml} ; 400 \mathrm{mg} / \mathrm{ml}$ dan $500 \mathrm{mg} / \mathrm{ml}$ dengan masing-masing diameter zona hambat 7,42 mm, 9,46 mm, $9,54 \mathrm{~mm}, 16,08 \mathrm{~mm}, 18,64 \mathrm{~mm}$ dan 25,28 mm. Simpulan: Ekstrak etanol daun sirsak memiliki aktivitas antibakteri dengan diameter zona hambat yang kuat pada konsentrasi $400 \mathrm{mg} / \mathrm{ml}$ dan $500 \mathrm{mg} / \mathrm{ml}$ namun tidak lebih baik dibandingkan kontrol positif siprofloksasin terhadap V. cholerae.

Kata kunci: diare; antibakteri; ekstrak etanol daun sirsak; vibrio cholerae
\end{abstract}

\begin{abstract}
Vibrio cholerae is one of the bacteria that caused diarrhoea. Some studies showed the occurrence of multidrug resistant against $V$. cholerae. Soursop plants (A. muricata L.) has secondary metabolites which have antibacterial activity. Objectives: To determine the antibacterial activity of ethanol of soursop leaves in inhibiting V. cholerae growth. Methods: Soursop leaves were extracted with maceration method using ethanol as a solvent. Phytochemical screening of ethanol extract of soursop leaves was performed using test tube method. Antibacterial activity test used disc diffusion method with the concentration of $25 \mathrm{mg} / \mathrm{ml}, 50 \mathrm{mg} / \mathrm{ml}, 100 \mathrm{mg} / \mathrm{ml}, 200 \mathrm{mg} / \mathrm{ml}, 400 \mathrm{mg} / \mathrm{ml}$, and $500 \mathrm{mg} / \mathrm{ml}$. Ciprofloxacin $5 \mu \mathrm{g} /$ disk was used as positive control while negative control used tween 80 . Results: Secondary metabolites contained in the ethanol extract of soursop leaves were alkaloid, phenol, flavonoid, saponin and tannin. Soursop leaves had antibacterial activity against $V$. cholerae at concentrations $25 \mathrm{mg} / \mathrm{ml} ; 50 \mathrm{mg} / \mathrm{ml} ; 100 \mathrm{mg} / \mathrm{ml} ; 200 \mathrm{mg} / \mathrm{ml} ; 400 \mathrm{mg} / \mathrm{ml}$; and $500 \mathrm{mg} / \mathrm{ml}$ with the diameter of inhibition zone respectively, $7.42 \mathrm{~mm}, 9.46 \mathrm{~mm}, 9.54 \mathrm{~mm}, 16.08 \mathrm{~mm}, 18.64 \mathrm{~mm}$, and 25.28 $\mathrm{mm}$. Conclusions: Ethanol extract of soursop leaves had the strongest antibacterial activity against $V$. cholerae at the concentration of $400 \mathrm{mg} / \mathrm{ml}$ and $500 \mathrm{mg} / \mathrm{ml}$ but weaker than the positive control of ciprofloxacin.
\end{abstract}

Keywords: diarrhoea; antibacterial; ethanol extract of soursop leaves; vibrio cholerae 


\section{PENDAHULUAN}

Diare merupakan suatu kondisi dimana seseorang buang air besar dengan konsistensi lembek atau cair, dengan frekuensi tiga kali sehari atau lebih (atau lebih sering dari biasanya (lebih dari 200 gram atau $200 \mathrm{ml} / 24$ jam). ${ }^{1}$ Secara global, diperkirakan ada 1,7 miliar kasus diare setiap tahun. Di Indonesia, menurut data dari Kemenkes RI pada tahun 2012, diare menempati peringkat pertama terbanyak pasies rawat inap di rumah sakit tahun 2010, dari 71.889 pasien yang dirawat 1.289 diantaranya meninggal dunia. ${ }^{2}$ Pada tahun 2015 jumlah penderita diare di Kota Pontianak dilaporkan sebanyak 13.532 kasus. Ini menunjukkan penyakit diare masih berpotensi menimbulkan Kejadian Luar Biasa (KLB). ${ }^{3}$

Diare dapat disebabkan oleh infeksi maupun non infeksi. Diare yang terbanyak adalah diare yang disebabkan oleh infeksi kuman patogen baik dari jenis virus, bakteri maupun parasit. Satu di antara bakteri yang dapat menyebabkan terjadinya diare adalah Vibrio cholerae. ${ }^{1} \mathrm{~V}$. cholerae merupakan bakteri gram negatif berbentuk batang yang melengkung, motil dan memiliki flagel polar. $V$. cholerae menghasilkan enterotoksin (toksin kolera) yang dapat menyebabkan terjadinya kolera. ${ }^{4}$ Penyakit kolera adalah penyakit infeksi saluran pencernaan yang disebabkan oleh bakteri $V$. cholerae dengan manifestasi klinik berupa diare. ${ }^{5}$ Seseorang yang terinfeksi bakteri tersebut dapat mengalami kehilangan cairan dalam jumlah banyak hingga menuju ke fase dehidrasi yang berat, bahkan dapat meninggal dalam jangka waktu beberapa jam setelah infeksi. ${ }^{1}$

Penyakit diare infeksi yang disebabkan oleh bakteri umumnya diatasi dengan penggunaan antibiotik. Namun tingginya harga antibiotik menjadi kendala utama bagi masyarakat yang berekonomi lemah untuk mengobati penyakit infeksi ini, disamping itu penggunaan antibiotik yang tidak benar dapat menyebabkan resistensi. ${ }^{6}$ Hasil penelitian menunjukkan adanya multidrug resistance $V$. cholerae terhadap beberapa antibiotik, yaitu sulfametoksazol, kotrimoksazol, trimetoprim, kloramfenikol, streptomisin, ampisilin, tetrasiklin, asam nalidiksat, dan gentamisin. Upaya alternatif pengobatan diperlukan untuk mengatasi resistensi antibiotik yaitu dengan menggunakan tanaman obat yang diharapkan dapat memberikan hasil yang efektif dalam membantu mengurangi penggunaan rehidrasi oral dan keparahan dari diare. ${ }^{7,8}$

Tanaman yang dapat digunakan sebagai pengobatan herbal satu diantaranya adalah sirsak (A. muricata L.), yang termasuk dalam famili Annonaceae. $^{9}$ Tanaman sirsak ini mempunyai manfaat yang besar untuk kehidupan manusia karena mengandung senyawa metabolik sekunder. Daun sirsak sudah banyak digunakan untuk sakit kepala, insomnia, penyakit hati, diabetes, hipertensi, dan sebagai anti inflamasi serta anti kejang dengan berbagai cara pengolahan. ${ }^{10}$ Buah sirsak digunakan 
sebagai obat alami untuk sakit rematik, neuralgia, artristis, diare, disentri, demam, malaria, parasit, rematik dan cacing, dan juga dimakan untuk meningkatkan ASI setelah melahirkan. ${ }^{11}$ Daun sirsak juga diketahui mengandung alkaloid, flavonoid, glikosida, saponin dan tanin yang memiliki mekanisme kerja sebagai antibakteri. ${ }^{12}$ Golongan annonaceae juga mengandung senyawa bioaktif yang disebut acetogenin yang banyak terkandung pada daun dan memiliki aktivitas terhadap sel kanker, serta dapat memberikan efek antibiotik. ${ }^{13}$

Berdasarkan penelitian tentang ekstrak etanol daun, batang, dan akar sirsak menunjukkan aktivitas antibakteri pada Staphylococcus aureus dan Escherichia coli, serta beberapa bakteri lain, seperti Pseudomonas aeruginosa, Klebsiella pneumonia, dan Bacillus subtilis. ${ }^{12}$ Ekstrak metanol daun sirsak juga diketahui memiliki aktivitas antibakteri terhadap bakteri Staphylococcus aureus, Salmonella typhimurinum, Escherichia coli, dan Streptococcus pyogenes. ${ }^{14}$ Ekstrak air buah sirsak memiliki aktivitas antibakteri terhadap bakteri $V$. cholerae dalam konsentrasi $50 \mu \mathrm{L} /$ disk menunjukkan ada kepekaan bakteri dengan diameter zona hambat $17 \mathrm{~mm}^{15}$

Berdasarkan pemaparan yang telah disampaikan mengenai tumbuhan sirsak menghasilkan zat produk potensial sebagai antibakteri. Penelitian mengenai uji aktivitas antibakteri ekstrak etanol daun sirsak (A. muricata L.) terhadap V. cholerae secara in vitro hingga saat ini belum pernah dilakukan, sehingga peneliti ingin melakukan penelitian ini guna melihat efek antibakteri dari daun sirsak.

\section{METODE}

Penelitian ini merupakan penelitian eksperimental murni yaitu melalui pengujian aktivitas antibakteri dari ekstrak daun sirsak secara in vitro dengan rancangan acak lengkap post test only control group design. Kelompok uji dan kelompok kontrol akan dinilai setelah diberikan perlakuan. Penelitian yang dilakukan meliputi pembuatan simplisia dan ekstrak etanol dari daun sirsak, serta skrining fitokimia larutan uji dan uji aktivitas antibakteri larutan uji terhadap Vibrio cholerae. Penelitian dilakukan bertujuan untuk menilai luas zona hambat yang dihasilkan dari ekstrak daun sirsak terhadap pertumbuhan $V$. cholerae.

Tumbuhan yang digunakan dalam penelitian ini adalah daun sirsak yang diambil di Jalan Pari Bugis, Kecamatan Sui Raya, Kabupaten Kuburaya. Daun sirsak yang telah dipanen kemudian dicuci menggunakan air mengalir. Setelah daun bersih selanjutnya dirajang kasar menjadi potongan-potongan kecil. daun sirsak kemudian dikeringkan secara tidak langsung di bawah sinar matahari. Daun sirsak yang telah mengalami proses pengeringan dinamakan simplisia. Simplisia dihaluskan dengan menggunakan blender sehingga diperoleh serbuk simplisia daun sirsak. Simplisia disimpan di dalam wadah yang kedap, disimpan di tempat yang kering dan bersih serta dijauhkan dari sinar matahari secara 
langsung. Pembuatan ekstrak daun sirsak dilakukan dengan metode maserasi dengan pelarut etanol 96\%. Hasil ekstrak etanol yang diperoleh kemudian dilakukan penguapan di bawah titik didih dengan rotary evaporator yang memiliki kelebihan hasil ekstrak etanol kental yang didapatkan melalui proses penguapan tidak rusak akibat suhu tinggi.

Analisis metabolit sekunder senyawa alkaloid, fenol, flavonoid, saponin dan tanin dengan menggunakan metode tabung. Pada pemeriksaan alkaloid dengan cara memasukkan $1 \mathrm{ml}$ ekstrak ke dalam tabung reaksi lalu ditambahkan 5 tetes kloroform dan beberapa tetes pereaksi mayer terbentuk endapan putih mengindikasikan adanya alkaloid. Pada pemeriksaan fenol dengan cara memasukkan $1 \mathrm{ml}$ ekstrak ke dalam tabung reaksi lalu ditambahkan beberapa tetes air panas dan pereaksi besi (III) klorida $1 \%$ terjadinya perubahan warna larutan menjadi warna hijau, biru, atau ungu menunjukkan adanya senyawa fenol. Pada pemeriksaan flavonoid dengan cara memasukkan $1 \mathrm{ml}$ ekstrak ke dalam tabung reaksi kemudian tambahkan sebuk magnesium sebanyak 0,1 gr dan larutan asam klorida pekat terjadi perubahan warna larutan menjadi warna kuning menandakan adanya senyawa flavonoid. Pada pemeriksaan saponin dengan cara memasukkan $2 \mathrm{ml}$ ekstrak ke dalam tabung reaksi ditambahkan $10 \mathrm{ml}$ air kemudian dikocok selama 10 menit terbentuknya busa setelah pengocokan menandakan adanya kandungan senyawa saponin. Pada pemeriksaan tanin dengan cara memasukkan $1 \mathrm{ml}$ ekstrak ke dalam tabung reaksi lalu ditambahkan beberapa tetes besi (III) klorida $5 \%$ terjadinya perubahan warna larutan menjadi warna biru tua menunjukkan adanya senyawa tanin. ${ }^{17,18}$

Uji aktivitas antibakteri ekstrak etanol daun sirsak pada penelitian ini menggunakan metode Kirby-Bauer. Metode ini dilakukan dengan cara membuat sumuran berukuran $6 \mathrm{~mm}$ kemudian dimasukkan ekstrak dengan variasi konsentrasi ekstrak etanol daun sirsak $500 \mathrm{mg} / \mathrm{ml}, 400 \mathrm{mg} / \mathrm{ml}, 200 \mathrm{mg} / \mathrm{ml}$, $100 \mathrm{mg} / \mathrm{ml}, 50 \mathrm{mg} / \mathrm{ml}$ dan $25 \mathrm{mg} / \mathrm{ml}$ yang diujikan ke media Mueller Hinton Agar yang telah ditanami bakteri Vibrio cholerae kemudian diinkubasi pada suhu $37^{\circ} \mathrm{C}$ selama 18-24 jam. Setelah diinkubasi, diamati ada tidaknya zona hambat atau zona bening yang terbentuk di sekitar sumuran menunjukkan adanya zona hambat atau adanya aktivitas antibakteri. ${ }^{19}$

Data diuji secara statistik dengan uji OneWay ANOVA untuk menilai pengaruh antibakteri ekstrak etanol annona muricata linn. terhadap vibrio cholerae. Untuk mengetahui signifikansi perbedaan dan rata-rata diameter zona hambat pertumbuhan bakteri pada setiap kelompok dilakukan uji Post Hoc menggunakan Least significance Difference (LSD).

\section{HASIL DAN PEMBAHASAN}

Skrining fitokimia dilakukan untuk mengetahui kandungan metabolit 
sekunder yang terkandung dalam ekstrak etanol daun sirsak (A. muricata L.) sehingga dapat diketahui senyawa yang berpotensi sebagai antibakteri. Pada skrining fitokimia ini, dilakukan uji golongan alkaloid, fenol, flavonoid, saponin dan tanin. Hasil skrining fitokimia pada ekstrak etanol daun sirsak dapat dilihat pada Tabel 1 dan Gambar 1.

Tabel 1. Hasil skrining fitokimia ekstrak etanol daun sirsak

\begin{tabular}{|c|c|c|c|c|}
\hline No. & Pemeriksaan & Pereaksi & Hasil & Keterangan \\
\hline 1. & Alkaloid & $\begin{array}{l}\mathrm{HCl} 2 \mathrm{~N} \text { ditambahkan: } \\
\text { Pereaksi Mayer }\end{array}$ & + & $\begin{array}{l}\text { Terbentuk endapan putih } \\
\text { hingga kuning }\end{array}$ \\
\hline 2. & Fenol & $\mathrm{FeCl}_{3} 1 \%$ & + & $\begin{array}{l}\text { Terbentuk warna } \\
\text { kehijauan }\end{array}$ \\
\hline 3. & Flavonoid & $\mathrm{Mg}+\mathrm{HCl}$ pekat & + & $\begin{array}{l}\text { Terbentuk warna } \\
\text { sampai merah }\end{array}$ \\
\hline 4. & Saponin & Aquades & + & $\begin{array}{l}\text { Terbentuk busa/buih yang } \\
\text { bertahan lebih dari } 10 \text { menit }\end{array}$ \\
\hline 5. & Tanin & $\mathrm{FeCl}_{3} 5 \%$ & + & $\begin{array}{l}\text { Terbentuk } \\
\text { kehijauan }\end{array}$ \\
\hline
\end{tabular}

Keterangan: $(+)=$ Hasil Positif (Terdeteksi senyawa metabolit sekunder)

$(-)=$ Hasil Negatif (Tidak terdeteksi senyawa metabolit sekunder)

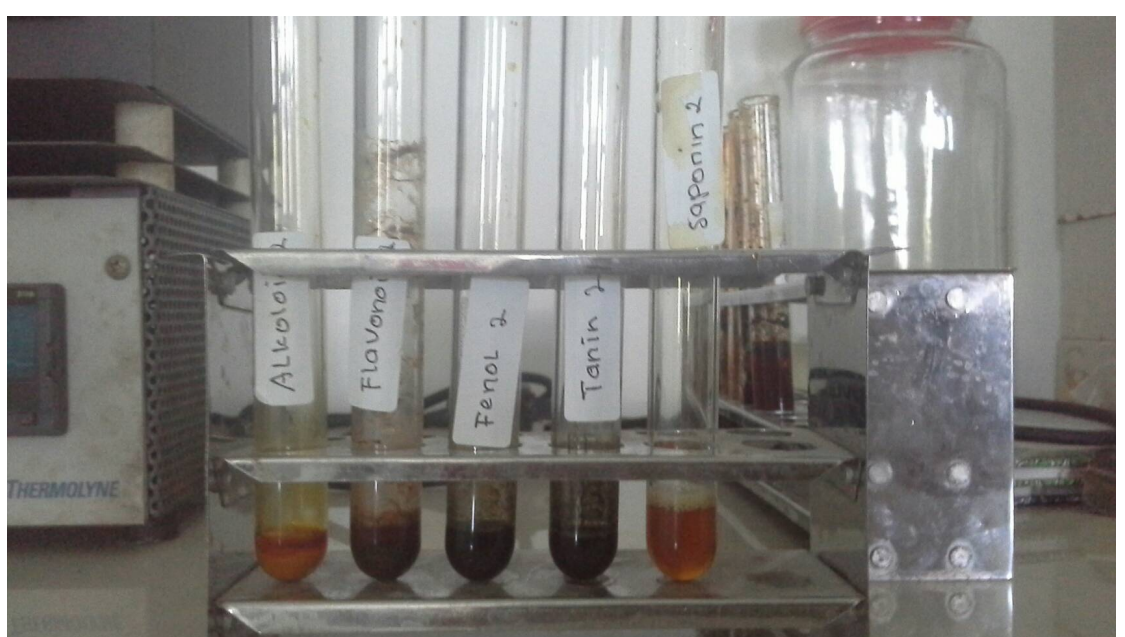

Gambar 1. Hasil Analisis Kandungan Metabolit Sekunder Daun Sirsak

Tabel 2. Karakterisasi Bakteri V. cholerae (Data Primer 2017)

\begin{tabular}{lcl}
\hline Karakterisasi & Hasil & Keterangan \\
\hline Media TCBS & + & Perubahan warna pada media TCBS dari hijau \\
& & menjadi kuning \\
Pewarnaan Gram & + & Gram Negatif, berbentuk seperti batang \\
Uji Katalase & + & Terbentuk gelembung udara \\
\hline
\end{tabular}

Tabel 3. Hasil Absorbansi Spektrofotometer

\begin{tabular}{llll}
\hline No. & Bahan & Panjang Gelombang & Hasil \\
\hline 1. & Blanko $(\mathrm{NaCl} \mathrm{0,9 \% )}$ & $540 \mathrm{~nm}$ & $0,064 \mathrm{~A}$ \\
2. & Mc Farland 0,5 & $540 \mathrm{~nm}$ & $0,113 \mathrm{~A}$ \\
3. & Suspensi Bakteri & $540 \mathrm{~nm}$ & $0,129 \mathrm{~A}$ \\
\hline
\end{tabular}


Bakteri uji pada penelitian ini adalah Vibrio cholerae yang diperoleh dari Balai Laboratorium Kesehatan Yogyakarta. Bakteri uji kemudian dilakukan peremajaan di Laboratorium Mikroskopis Fakultas Kedokteran Universitas Tanjungpura. Berdasarkan surat keterangan yang diberikan dan hasil karakterisasi diketahui bahwa bakteri uji merupakan V. cholerae. Hasil karakterisasi dapat dilihat pada Tabel 2 dan Gambar 2.

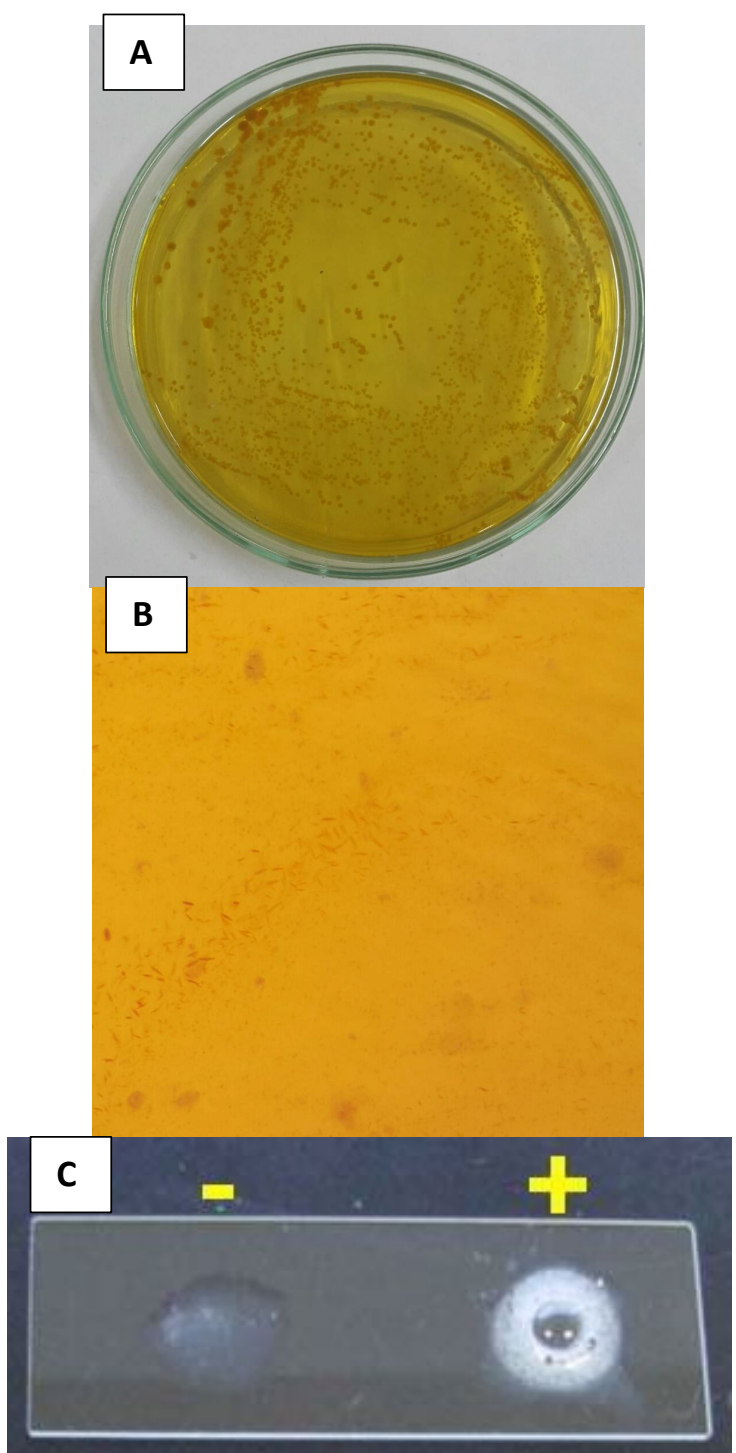

Gambar 2. Hasil Karakterisasi Bakteri V. cholerae (A) Media TCBS, (B) Pewarnaan Gram, dan (C) Uji Katalase
Bakteri V. cholerae disuspensikan dalam larutan $\mathrm{NaCl}$ 0,9\%. Suspensi bakteri disetarakan menggunakan Spektrofotometer pada panjang gelombang $540 \mathrm{~nm}$ dengan standar McFarland 0,5 (1,5x108 CFU/ml) dengan hasil absorbansi dapat dilihat pada Tabel 3. Hasil uji antibakteri terhadap kontrol negatif yaitu tween 80 terhadap $V$. cholerae tidak memberikan zona hambat pada pertumbuhan $V$. cholerae, hal ini menunjukkan hasil positif pada konsentrasi uji tidak dipengaruhi oleh bahan pelarut. Sedangkan hasil uji terhadap kontrol positif yaitu siprofloksasin memberikan rata-rata diameter zona hambat sebesar 30,71 mm. Hal ini menunjukkan bahwa siprofloksasin masih sensitif sebagai antibakteri terhadap $V$. cholerae sesuai dengan standar CLSI yang menyatakan siprofloksasin dikatakan sensitif terhadap $V$. cholerae apabila memiliki diameter zona hambat $\geq 21 \mathrm{~mm}$, hasil dapat dilihat pada Tabel $4 .^{20}$

Berdasarkan hasil pengamatan uji aktivitas antibakteri ekstrak etanol daun sirsak terhadap pertumbuhan bakteri $V$. cholerae memberikan hasil terdapat penghambatan pertumbuhan bakteri $V$. cholerae pada pemberian ekstrak etanol daun sirsak pada semua konsentrasi uji. Hal ini menunjukkan ekstrak etanol daun sirsak memiliki aktivitas antibakteri terhadap pertumbuhan $V$. cholerae. Zona hambat ekstrak etanol daun sirsak terhadap $V$. cholerae dapat dilihat pada Tabel 5. 


\section{Diameter Zona Hambat (mm)}

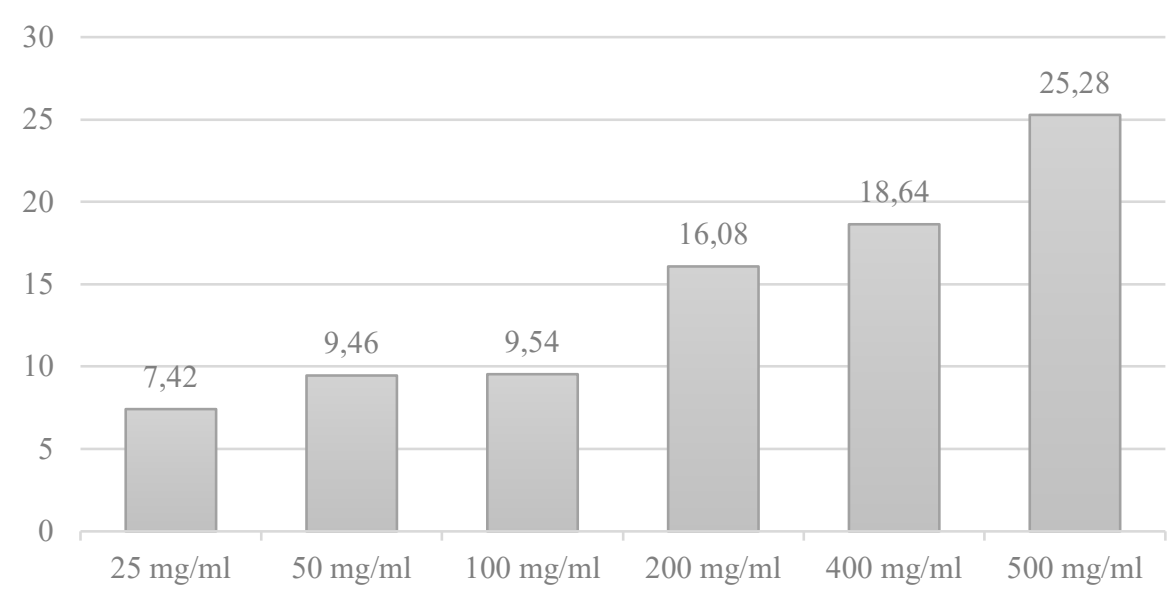

Gambar 3. Histogram Hasil Uji Aktivitas Antibakteri Ekstrak Etanol Daun Sirsak (A. muricata L.)

Tabel 4. Diameter Zona Hambat Kontrol Positif dan Kontrol Negatif Terhadap V. cholerae

\begin{tabular}{llcccc}
\hline No. & Konsentrasi & \multicolumn{3}{c}{ Diameter Zona Hambat $(\mathrm{mm})$} & Rata-rata \\
& & $\mathrm{I}$ & $\begin{array}{c}\text { Pengulangan ke- } \\
\text { II }\end{array}$ & III & (mm) \\
\hline 1. & Siprofloksasin & 30,45 & 29,78 & 31,90 & 30,71 \\
2. & Tween 80 & 0 & 0 & 0 & 0 \\
\hline
\end{tabular}

Tabel 5. Diameter Zona Hambat Ekstrak Etanol Daun Sirsak (A. muricata L.) Terhadap V. cholerae

\begin{tabular}{llcccc}
\hline No. & Konsentrasi $(\mathrm{mg} / \mathrm{ml})$ & \multicolumn{3}{c}{ Diameter Zona Hambat $(\mathrm{mm})$} & $\begin{array}{c}\text { Rata-rata } \\
\text { Pengulangan ke- }\end{array}$ \\
& & I & II & III & \\
\hline 1. & 500 & 25,2 & 24,67 & 25,98 & 25,28 \\
2. & 400 & 19,12 & 18,34 & 18,45 & 18,64 \\
3. & 200 & 16,14 & 15,23 & 16,86 & 16,08 \\
4. & 100 & 10,33 & 9,65 & 8,65 & 9,54 \\
5. & 50 & 9,12 & 10,02 & 9,23 & 9,46 \\
6. & 25 & 7,42 & 8,34 & 6,50 & 7,42 \\
\hline
\end{tabular}

Hasil pengamatan aktivitas antibakteri menunjukkan diameter zona hambat mengalami peningkatan seiring dengan peningkatan konsentrasi ekstrak etanol daun sirsak seperti yang tertera pada gambar di atas. Ekstrak etanol daun sirsak (A. muricata L.) memiliki aktivitas antibakteri terhadap pertumbuhan $V$. cholerae dengan rata-rata diameter zona hambat 7,42-25,28 $\mathrm{mm}$ pada konsentrasi
$25 \mathrm{mg} / \mathrm{ml}, 50 \mathrm{mg} / \mathrm{ml}, 100 \mathrm{mg} / \mathrm{ml}, 200$ $\mathrm{mg} / \mathrm{ml}, 400 \mathrm{mg} / \mathrm{ml}$ dan $500 \mathrm{mg} / \mathrm{ml}$. Hal ini disebabkan aktivitas yang ditimbulkan oleh suatu ekstrak berbanding lurus dengan kadar konsentrasi. Semakin tinggi konsentrasi suatu ekstrak maka semakin tinggi pula kandungan senyawa antibakteri yang terlarut di dalamnya, hasil dapat dilihat pada Gambar 3. 
Data yang diperoleh dari hasil penelitian dilakukan uji statistik terhadap data tersebut. Uji normalitas dan uji homogenitas menunjukkan bahwa data tersebut terdistribusi normal dan memiliki varians yang sama (homogen). Selanjutnya data dapat dilakukan uji One-Way ANOVA $^{21}$ untuk mengetahui apakah terdapat pengaruh antibakteri ekstrak etanol annona muricata linn. terhadap bakteri $V$. cholerae.

Hasil uji One-Way ANOVA menunjukkan nilai signifikansi sebesar $0,000(p<0,05)$, sehingga dapat disimpulkan bahwa terdapat pengaruh konsentrasi ekstrak etanol daun sirsak pada hambatan bakteri V. cholerae. Selanjutnya untuk mengetahui signifikansi perbedaan dan rata-rata diameter zona hambat pertumbuhan bakteri pada setiap kelompok dilakukan uji Post Hoc menggunakan Least significance Difference (LSD).

Dari hasil uji Post Hoc LSD terdapat perbandingan konsentrasi yang tidak signifikan yaitu pada konsentrasi $50 \mathrm{mg} / \mathrm{ml}$ dengan $100 \mathrm{mg} / \mathrm{ml}$ dengan nilai signifikansi 0,894. Hal tersebut dikarenakan perbedaan tingkat konsentrasi pada ekstrak etanol, sehingga mendapatkan diameter zona hambat yang tidak berbeda secara signifikan antar konsentrasi tersebut.

Aktivitas antibakteri disebabkan oleh terdapatnya suatu zat atau senyawa antibakteri yang dapat menghambat pertumbuhan bakteri atau menyebabkan kematian bakteri dengan beberapa mekanisme yaitu penghambatan terhadap sintesis dinding sel, penghambatan terhadap fungsi membran sel, penghambatan terhadap sintesis protein atau penghambatan terhadap sintesis asam nukleat. $^{5}$

Aktivitas antibakteri ini dipengaruhi oleh beberapa faktor yaitu: konsentrasi ekstrak, kandungan senyawa antibakteri, daya difusi ekstrak dan jenis bakteri yang dihambat. Aktivitas antibakteri terhadap $V$. cholerae oleh ekstrak etanol daun sirsak disebabkan oleh senyawa metabolit sekunder yang terdapat dalam ekstrak tersebut yaitu alkaloid, fenol, flavonoid, saponin dan tanin. Penghambatan pertumbuhan bakteri oleh metabolit sekunder tersebut memiliki beberapa mekanisme yang mengganggu permeabilitas dari membran sel (tanin, saponin dan flavonoid), menghambat sintesis dinding sel (alkaloid), mendenaturasi protein sel (flavonoid dan fenol) dan menghambat sintesis asam nukleat (tanin). ${ }^{5,22,23}$

Flavonoid memiliki aktivitas antibakteri dengan cara mengikat asam amino nukleofilik pada protein dan inaktivasi enzim. Senyawa saponin menyebabkan penurunan tegangan permukaan sehingga mengakibatkan naiknya permeabilitas atau kebocoran sel dan mengakibatkan senyawa intraseluler akan keluar. Senyawa tanin bekerja dengan cara mengikat protein sehingga pembentukan dinding sel bakteri terhambat. Aktivitas tanin dapat menghambat pertumbuhan bakteri karena mempunyai daya antibakteri dengan cara presipitasi protein dan menyebabkan 
membran sel bakteri mengerut yang mengakibatkan perubahan permeabilitas sel menjadi menurun. ${ }^{22}$

Mekanisme membran sel bakteri berfungsi sebagai sawar selektif yang mengatur keluar masuknya senyawa ke dalam sel bakteri. Sehingga melalui membran sel ini, beberapa senyawa ditranspor secara aktif. Terganggunya permeabilitas dari membran sel yang disebabkan oleh metabolit sekunder yang terdapat dalam daun sirsak yaitu tanin, saponin, dan flavonoid menyebabkan terganggunya fungsi dari membran sel sebagai sawar selektif terhadap beberapa senyawa, yang menyebabkan terjadinya kebocoran sel. Kebocoran sel bakteri menyebabkan keluarnya komponen sel/organel yang berfungsi untuk menjalankan kehidupan sel bakteri dan mempertahankan fungsi normal kehidupan sel bakteri. Apabila semua fungsi tersebut terganggu akan mengakibatkan kerusakan dari sel bakteri yang menyebabkan bakteri menjadi lisis dan terjadi kematian sel bakteri. ${ }^{5,23}$
Mekanisme antibakteri daun sirsak selain menyebabkan terjadinya gangguan pada permeabilitas dari membran sel juga dengan menyebabkan terjadinya denaturasi protein membran sel. Senyawa yang berperan dalam hal ini adalah flavonoid dan fenol. Denaturasi protein adalah kerusakan struktur tersier dari protein yang menyebabkan terjadinya kerusakan pada protein dan menyebabkan protein tidak dapat berfungsi. Protein berfungsi dalam metabolisme sel bakteri, kerusakan protein dapat menyebabkan terganggunya proses metabolisme bakteri sehingga terganggunya kehidupan sel bakteri dan kematian bakteri. ${ }^{23}$

\section{SIMPULAN}

Ekstrak etanol daun sirsak (A. muricata L.) memiliki aktivitas antibakteri terhadap pertumbuhan $V$. cholerae. Ekstrak etanol daun sirsak ( $A$. muricata $L$.) mengandung senyawa metabolit sekunder yaitu alkaloid, fenol, flavonoid, saponin dan tanin.

\section{DAFTAR PUSTAKA}

1. Fauci AS, Braunwald E, Isselbacher KJ, Wilson JD, Martin JB, Kasper DL. Harrison's Principles of Internal Medicine. 19 ${ }^{\text {th }}$ Edition. New York: McGraw-Hill Companies Inc; 2015.

2. Kementerian Kesehatan Republik Indonesia. Profil data kesehatan Indonesia tahun 2011. Jakarta: Kementerian Kesehatan RI; 2012.

3. Dinas Kesehatan Kota Pontianak. Profil Kesehatan Kota Pontianak Tahun 2015. Pontianak: Dinas Kesehatan Kota Pontianak; 2016. P.34-36.

4. Parija SC. Textbook of Microbiology \& Immunology. $2^{\text {nd }}$ Edition. Gurgaon: Elsevier India; 2012.

5. Brooks GF, Butel JS, Morse SA. Jawetz, Melnick, \& Adelberg's Medical Microbiology. $27^{\text {th }}$ Edition. New York: The McGraw-Hill Companies Inc; 2016. 
6. Utami ER. Antibiotika, resistensi, dan rasionalitas terapi. El-Hayah. 2011; 1(4):191-198. doi: 10.18860/elha.v1i4.1783.

7. Okoh Al, Igbinosa EO. Antibiotic susceptibility profiles of some Vibrio strains isolated from wastewater final effluents in a rural community of the Eastern Cape Province of South Africa. BMC Microbiol. 2010; 10:143. doi: 10.1186/1471-2180-10-143.

8. Shrestha SD, Malla S, Adhikari BR, Shakya G, Basnyat SR, Sharma S. Antibiotic susceptibility patterns of Vibrio cholerae isolates. J Nepal Med Assoc. 2010; 49(197):232-6.

9. Hermawan GP, Laksono H, Sumantri I. Ekstraksi Daun Sirsak (Annona muricata L) menggunakan Pelarut Etanol. Jurnal Teknologi Kimia dan Industri. 2013; 2(2):111-5.

10. de Sousa OV, Vieira GD, de Jesus RG, de Pinho J, Yamamoto CH, Alves MS. Antinociceptive and anti-inflammatory activities of the ethanol extract of Annona muricata L. leaves in animal models. Int J Mol Sci. 2010; 11(5):2067-78. doi: 10.3390/ijms11052067.

11. Mishra S, Ahmad S, Kumar N, Sharma BK. Annona muricata (the cancer killer): a review. Glob J Pharma Res. 2013; 2(1):1613-8.

12. Vijayameena C, Subhashimi G, Loganayagi M, Ramesh B. Original Research Article Phytochemical screening and assessment of antibacterial activity for the bioactive compounds in Annona muricata. Int J Curr Microbiol App Sci. 2013; 2(1):1-8.

13. Sawant TP, Gogle DP. A Brief Review on recent Advances in Clinical Research of Annona muricata. Int J Uni Pharm Biol Scie. 2014; 3(3):267-304.

14. Solomon-Wisdom GO, Ugoh SC, Mohammed B. Phytochemical Screening and Antimicrobial activities of Annona muricata (L) leaf extract. J Biol Chem Pharm Sci. 2014; 2(1):1-7.

15. Viera GHF, Mourao JA, Angelo AM, Costa RA, Vieira RHS. Antibacterial effect (in vitro) of Moringa oleifera and Annona muricata against Gram positive and Gram negative bacteria. Rev Inst Med Trop Sao Paulo. 2010; 52(3):129-32.

16. Gajalakshmi S, Vijayalakshmi S, Devi RV. Phytochemical and Pharmacological Properties of Annona muricata: a review. Int J Pharm Pharm Sci. 2012; 4(2):3-6.

17. Lailatul L, Kadarohman A, Eko R. Efektivitas Biolarvasida Ekstrak Etanol Limbah Penyulingan Minyak Akar Wangi (Vetiveria zizanoides) terhadap Larva Nyamuk Aedes aegypti, Culex Sp., dan Anopheles sundaicus. Jurnal Sains dan Teknologi Kimia. 2010; 1(1):59-65.

18. Atmoko T, Ma'ruf A. Toxicity Testing and Phytochemical Screening of Orangutan Food Extracts to Larvae of Artemia salina L. Jurnal Penelitian Hutan dan Konservasi Alam. 2009; 6(1):37-45.

19. Monks NR, Lerner C, Henriques AT, Farias FM, Schapoval EES, Suyenaga ES, et al. Anticancer, antichemotactic and antimicrobial activities of marine sponges collected off the coast of Santa Catarina, Southern Brazil. J Exp Marine Bio Eco. 2002; 281(1):1-12. doi: 10.1016/500220981(02)00380-5.

20. Clinical and Laboratoryy Standars Institute (CLSI). M02-A12 Performance Standards for Antimicrobial Disk Susceptibility Tests; Approved Standards--Twelfth Edition. Wayne, PA: Clinical and Laboratory Standards Institute; 2015.

21. Siregar S. Metode penelitian kuantitatif: dilengkapi dengan Perbandingan Perhitungan Manual \& SPSS. Jakarta: Prenada Media; 2013.

22. Sabir A. In vitro Antibacterial Activity of Flavonoids Trigona sp Propolis Against Streptococcus mutans. Dental Journal. 2005; 38(3):135-41. 
23. Katzung BG, Masters SB, Trevor AJ. Basic \& Clinical Pharmacology. $13^{\text {th }}$ Edition. New York City: The McGraw-Hill Companies Inc; 2014. 